\title{
ЗНАЧЕНИЕ АНАЛИЗА ТЕХНИКО-ТАКТИЧЕСКИХ ДЕЙСТВИЙ ФУТБОЛИСТОВ ВЫСОКОЙ КВАЛИФИКАЦИИ ДЛЯ СОВЕРШЕНСТВОВАНИЯ РЕКРЕАТИВНЫХ ТЕХНОЛОГИЙ
}

\section{THE ANALYZIS TECHNICAL AND TACTICAL ACTIONS OF HIGHLY QUALIFIED SOCCER PLAYERS FOR IMPROVING RECREATIONAL TECHNOLOGIES}

\section{Alkhakim Alaa \\ N. Zakharieva \\ P. Makeev}

Summary: The article presents the results of the analysis technical and tactical actions of 17 highly qualified soccer player. The methodological approach to the rehabilitation of qualified football players using the conjugate method justified.

Keywords: soccer players, playing roles, technical and tactical actions, recreational technologies.
Алхаким Алаа

аспирант, ФГБОУ ВО «Российский государственный университет физической культуры, спорта, молодёжи и туризма (ГЦОЛИФК)», Москва a.h16n1988@gmail.com

Захарьева Наталья Николаевна Ә.м.н., профессор, ФГБОУ ВО «Российский государственный университет физической культуры, спорта, молодёжи и туризма (ГЦОЛИФК)», Москва zakharyeva.natalia@mail.ru

Макеев Павел Викторович тренер сборной команды, РГУФКСМиТ в Спорт Академ. клубе города Москвы. pave12166@mail.ru

Аннотация: В статье представлены результаты анализа технико-тактических действий 17 высоко квалифицированных футболистов. Обоснован методический подход к реабилитации квалифицированных футболистов с использованием сопряженного метода.

Ключевые слова: футболисты, игровое амплуа, технико-тактические действия, рекреативные технологии.

Методы и организация исследования анализ научно-методической литературы, анализ технико-тактических действий игроков футбольной команды РГУФКСМиТ на тренировке и товарищеских матчах в городах Москве и Химки; физиологическое и педагогическое наблюдение, методы математической статистики. Обследовано 17 футболистов высокой квалификации, члены сборной команды РГУФКСМиТ по футболу; средний

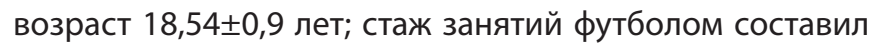
$12,46 \pm 1,08$ лет.

\section{Результаты исслеАований} нировочного процесса футболистов является анализ структуры соревновательной деятельности игроков различного амплуа [4]. Многофакторная структура подготовки футболиста диктует необходимость тщательного анализа технико-тактической подготовки каждого игрока команды, что определяет индивидуальный подход к современным рекреативным технологиям для футболистов различного амплуа.

Цель исследования научное обоснование методического подхода к разработке рекреативных технологий для футболистов высокой квалификации различного игрового амплуа на основании анализа их технико-тактических действий.
Проведено обследование сборной команды РГУФКСМиТ по футболу - 17 спортсменов - футболистов высо-

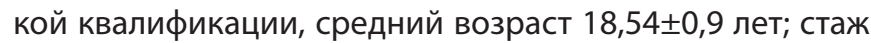

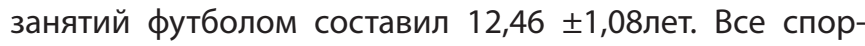
тсмены регулярно тренируются в Спорт Академ. клубе города Москва. На момент обследования футболисты не имели острых и обострения хронических заболеваний. Исследования проведены в часы физиологической симпатикотонии (с 9.00. до 13.00.). Согласно данным анкетирования 17 человек, играющих сейчас в одной команде, регулярно тренировались в разных городах и климатических зонах: городе Москва -13 чел.; 2 чел. в городе Новосибирске; 1чел. в Ставрополе и 1 чел. в Московской 
области. ПО данным анкетирования и беседы отмечена редкая заболеваемость игроков команды ОРВИ 1-2 раза, только 2 игрока (1 защитник и 1 полузащитник) отмечают частоту ОРВИ 3- 4 раза в год. У 2 - х спортсменов были отмечены хронические заболевания - хронический тонзиллит; у 1 - ого футболиста выявлена аллергия. Обращает внимание, что большинство игроков команды в 56,45\% (9 чел.) имели различные профессиональные травмы: сотрясение головного мозга; разрыв связок голеностопного сустава; разрыв четырехглавой мышцы бедра; перелом пятой плюсневой кости; перелом ключицы; травма мениска левой ноги; пяточные шпоры; разрывы связок на лодыжке обеих ног, что представлено на рис.1, как структура травм ОДА (опорно-двигательного аппарата).

Треть спортсменов была оперирована из-за профессиональных травм. Кроме того, 2-ое спортсменов футболистов были оперированы по поводу аденоидов; 1чел. по поводу искривления носовой перегородки; 1 чел. - по поводу пупочной грыжи. Спортивный анамнез (родители - спортсмены -футболисты) по данным анкетирования у 23,53 \% игроков положителен. Наивысшие достижения при занятиях футболом по данным беседы отметили только 3 игрока: 1 чел. (крайний защитник) Чемпион России в зоне Москва; 1 чел.(полузащитник) играл в сборной команде Московской области; 1 чел. (крайний защитник) - 4 - х кратный чемпион в зоне премьер лиги - зона Москвы.

Для анализа результатов научного физиологического эксперимента проведено физиологическое наблюдение за футболистами команды во время физиологического тестирования, тренировки и вовремя 2-х игр в соревновательном и подготовительном периодах спортивной подготовки.

Как показали результаты наблюдения, все игроки активно выполняли свои функциональные обязанности в команде согласно своему амплуа в полном объеме.

При наблюдении за игроками в ходе игры у каждого игрока оценивалось качество технико-тактического мастерства (ТТД) (таблица -1).

По результатам физиологического наблюдения разрабатывались модели эффективности ТТД для каждого игрового амплуа. Проведен анализ технико-тактических действий игроков различного амплуа по данным полевых наблюдений (ТТД). Согласно полученным данным, анализировались результаты игр в подготовительном и соревновательном периодах спортивной подготовки. Как показали результаты физиологического наблюдения, игроки команды выполняют свои игровые функции в полном объеме. Игроки команды были разбиты по амплуа и активной игре на своих игровых линиях:

1. Игроки линии нападения -нападающие;

2. Игроки средней линии- полузащитники;

3. Игроки задней линии защиты -защитники

При наблюдении за игроками в ходе игры у каждого игрока оценивалось качество ТТД. По полученным дан-

\section{СТРУКТУРА ТРАВМ ОПОРНО- ДВИГАТЕЛЬНОГО АППАРАТА У ФУТБОЛИСТОВ ВЫСОКОЙ КВАЛИФИКАЦИИ (ДАННЫЕ АНКЕТИРОВАНИЯ)}
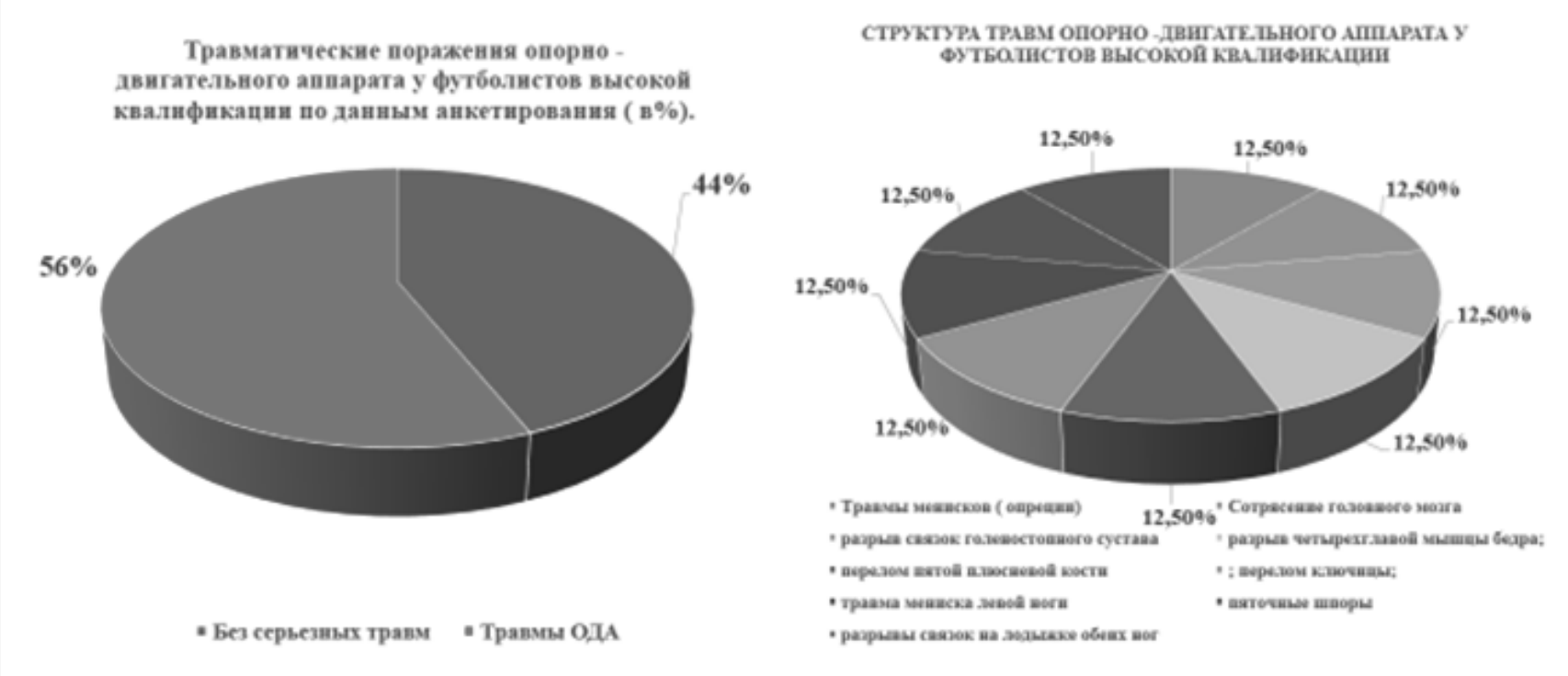

Рис. 1. Структура заболеваний спортсменов-футболистов 
Таблица 1.

Критерии оценка качества технико-тактического мастерства футболистов высокой квалификации.

\begin{tabular}{|l|l|l|}
\multicolumn{1}{|c|}{ ПЕРЕДАЧИ } & \multicolumn{1}{|c|}{ ВЕДЕНИЕ МяЧА } \\
\hline $\begin{array}{l}\text { 1. передачи мяча на короткое и среднее расстояние выполняемые назад } \\
\text { менее 30м; }\end{array}$ & $\begin{array}{l}\text { 1. ведение мяча и отбор мяча у соперника; } \\
\text { 2. единоборства за мяч, когда он вверху; }\end{array}$ & $\begin{array}{l}\text { 1. удары по воротам головой } \\
\text { 2. удары по воротам ногами }\end{array}$ \\
$\begin{array}{l}\text { 2. передачи мяча на короткое и среднее расстояние выполняемые вперед } \\
\text { менее 30м; }\end{array}$ & $\begin{array}{l}\text { 3. борьба за мяч внизу, когда мяч ничей; } \\
\text { 3. Передехват мяча. }\end{array}$ & \\
4. Передачи мяча, выполненные от фланга; & & \\
5.Качество «обводок»: удачные и неудачные. & & \\
\hline
\end{tabular}

\section{БРАК ТЕХНИКО - ТАКТИЧЕСКИХ ДЕЙСТВИЙ ФУТБОЛИСТОВ РАЗЛИЧНОГО АМПЛУА ПО ДАННЫМ ФИЗИОЛОГИЧЕСКОГО НАБЛЮДЕНИЯ В ПОДГОТОВИТЕЛЬНЫЙ ПЕРИОД СПОРТИВНОЙ ПОДГОТОВКИ (в \%)}

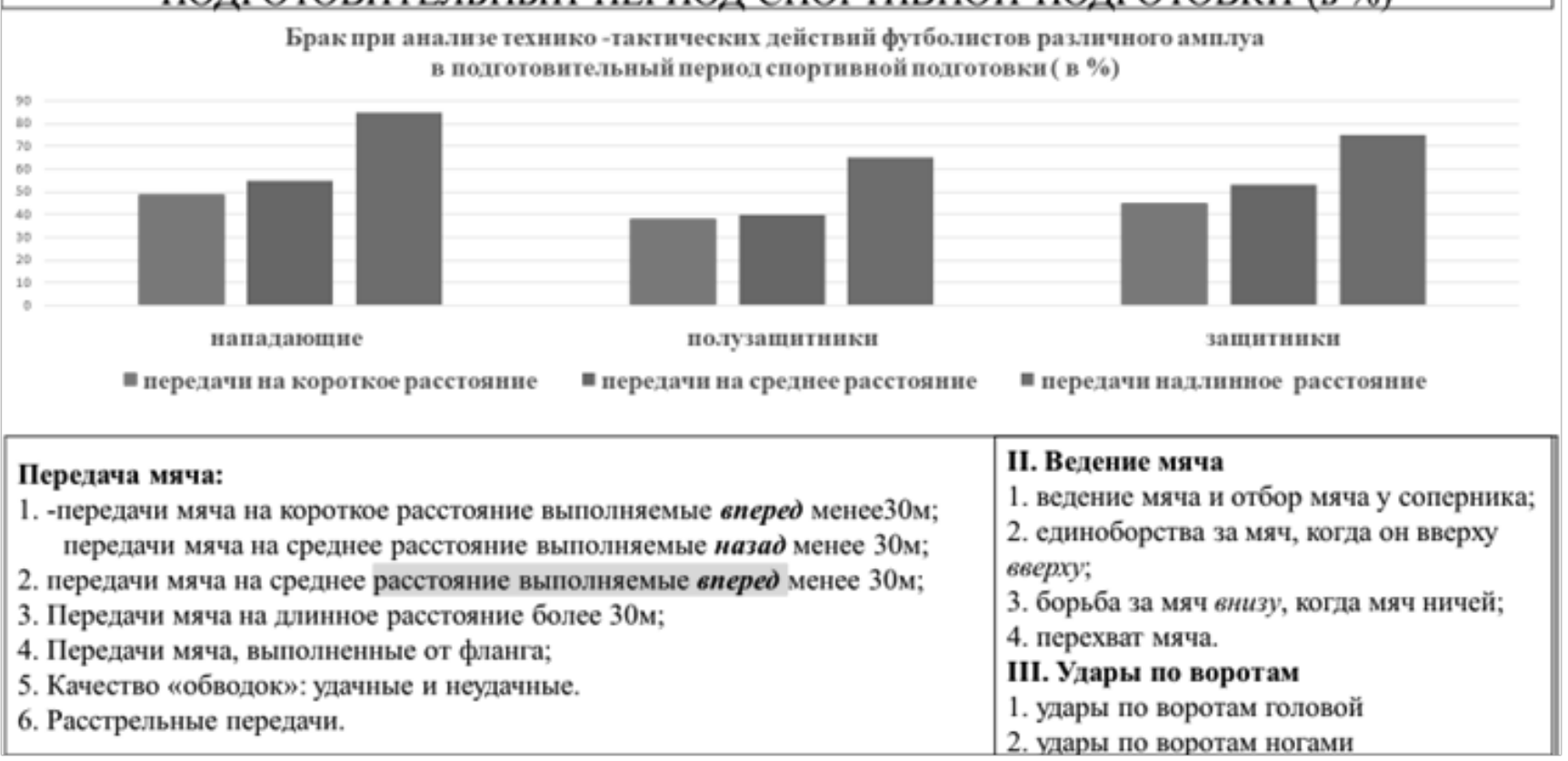

Рис. 2. Результат брака технико - тактического мастерства футболистов различного амплуа по данным физиологического наблюдения (в \%).

ным вычисляли процент ошибок (брака) в подготовительном периоде спортивной подготовки (рис. 2.)

Как видно из рисунка 2, наименьший процент не точно выполненных данных отмечен у футболистов, играющих на средней линии - полузащитников, что может быть связано как с внутренними факторами: с более широкими особенностями функционального состояния полузащитников, развитием физических качеств, степень выраженности технико-тактического мастерства, степенью активности конкретной наблюдаемой игры; игры в различных фазах команды; набора индивидуальных динамических стереотипов и способности к двигательной экстраполяции у конкретных игроков команды; с внешними факторами: устойчивыми для игры в футбол (распределение основных тактических функций по игровым линиям); с переменными факторами: индивидуальные возможности климатической адаптации, текущий ре- зультат матча, задачи, стоящие перед командой [2].

Как видно из рисунка 2, полузащитники и во вторую очередь защитники более успешны в качестве передач на средние и длинные дистанции, в сравнении с нападающими, но это результат 2 - х игр и влияющих факторов довольно много. По результатам технико-тактических действий разработаны полезные модели, характеризующие точность тактических действий игроков различного амплуа, что является отражение развития их функциональных резервов и развития физических качеств и может быть использовано в построении рекреативных технологий. При анализе динамики (от подготовительного периода к соревновательному) точные передачи на длинное расстояние отмечена положительная динамика, которая более выражена у нападающих и полузащитников, защитники практически без динамики. 


\section{Выво $\Delta ы$}

1. Общекомандный показатель объема техникотактических действий (передачи на короткое, среднее и длинное расстояние; передачи мяча, выполненные от фланга; ведение мяча и отбор у соперника; качество обводок (удачные/неудачные); отбор; перехват мяча; игра головой, удары по воротам ногой и головой) и точность выполнения действий с мячом в игре определяют уровень технико-тактической подготовленности футболистов высокой квалификации.
2. Последовательность распределения тренировок для футболистов СВК с учетом их технико-тактических действий в мезоцикле должно включать в себя подготовительные микроциклы: втягивающий -7 дней; развивающий -14 суток; ударный -7 суток и восстановительный - 7 дней. Направленность занятий должна быть с преимущественным развитием общей и специальной выносливости команды в целом. Для совершенствования технологий воздействия на технико-тактическую подготовленность футболистов рекомендовано использовать сопряженный метод.

\section{ЛИТЕРАТУРА}

1. Андреева В.С., Информационные технологии в сфере физической культуры и спорта//Андреева В.С., Миронова С.П. Российский государственный профессионально-педагогический университет, г. Екатеринбург [Электронный ресурс]. - 0бращение 14.02.2021.

2. Байрачный, О.В. Анализ соревновательной деятельности футболистов высокой квалификации с учетом игровых амплуа/ Байрачный 0.B. Киев. -2008. $-C$.

3. Безуглов Э.Н. Мониторинг функционального состояния футболистов высокой квалификации в течение соревновательного сезона//Вестник спортивной науки / Э.Н. Безуглов. - 2011. - №. 3.- С.25-30.

4. Белаид Моджахед Структура и содержание тренировочного процесса юных футболистов подготовительного периода на этапе спортивного совершенствования// Белаид Моджахед дисерт. на соиск.. ученой степени к.п.н. Тамбов -2016.- 135.

5. Губа, В.П. Комплексный подход в оценке функционального состояния профессиональных спортсменов//Вестник спортивной науки / В.П. Губа, В.В. Маринич. - 2013. - №. 6. - С.47-51.

6. Павличенко П.П. Влияние игровой нагрузки на функциональное состояние профессиональных футболистов //Мир медицины и биологии / П.П. Павличенко. - Т. 11. - №. 1. 2015, - С.49-64.

7. Шамардин В.Н. Моделирование подготовленности квалифицированных футболистов: Учеб. Пособие / В.Н. Шамардин. -Днепропетровск. - Пороги, 2002. -200 c.

8. Hoff J. Training and testing physical capacities for elite soccer players //Journal of sports sciences. - 2005. - T. 23. - №. 6. - P. 573-582. 